\title{
Plasma lipids and their interrelationship in Turkish adults
}

\author{
Altan Onat, Günsel Şurdum-Avcı, Mustafa Şenocak, Ender Örnek, Yavuz Gözükara
}

\begin{abstract}
Study objective-The aim was to describe the plasma total cholesterol and triglyceride profiles in a random sample of Turkish adults and analyse the effects of certain coronary risk factors on these levels.

Design-This was a cross sectional population based survey.
\end{abstract}

Setting -59 communities scattered in all seven geographical regions of Turkey were surveyed in the summer of 1990.

Subjects-A random sample of 3689 men and women 20 years of age and over was studied.

Measurements and main resultsPlasma total cholesterol, triglycerides, glucose (using Reflotron and with partial validation in reference laboratory), weight, height, and blood pressure were measured, and information on smoking, physical activity, and family income obtained. Hypercholesterolaemia ( $\geqslant 6.5 \mathrm{mmol} / \mathrm{litre}$, $250 \mathrm{mg} / \mathrm{dl}$ ) prevailed in $8.5 \%$, and hypertriglyceridaemia ( $>2.25 \mathrm{mmol} / \mathrm{litre}$, $200 \mathrm{mg} / \mathrm{dl}$ ) in $16.6 \%$ among men and women aged 40-59 years of age. Age adjusted total cholesterol values were $4.8 \mathrm{mmol} /$ litre $(185 \mathrm{mg} / \mathrm{dl})$ in men and $5 \mathrm{mmol} /$ litre $(192 \mathrm{mg} / \mathrm{dl}$ ) in women. A steep rise appeared in mean cholesterol levels between the ages of 20-29 and 40-49 years, in a ratio greater than the available data from some other populations indicated. Mean total cholesterol values increased substantially in both genders with diminishing grades of physical activity, rising serum triglyceride levels, in urban (opposed to rural) residents, in men with increasing income levels, and in the younger adults with rising body mass index.

Conclusions-Turkish adults have comparatively low levels of total cholesterol and medium to moderately high levels of triglycerides. Lifestyle factors affect these levels in Turks as in other populations.

Turkish Society of Cardiology, Istanbul, Turkey A Onat

G Surdum-Avcı

$M$ Şenocak

E Örnek

Y Gözükara

Correspondence to: Professor Altan Onat, at Nisbetiye cad 37/24, Etiler 80630, Istanbul, Turkey f Epidemiol Community Health 1992; 46: 470-476

Serum or plasma cholesterol concentration is an established risk indicator in the development of atherosclerosis and particularly of coronary heart disease, both in individuals and in communities. ${ }^{1}$ In contrast to many other European nations, reliable data on the prevalence of risk factors in the inhabitants of Turkey, a populous nation, have not hitherto been available. Therefore the Turkish Society of Cardiology, supported by the
Turkish Ministry of Health, conducted a survey of a representative sample of adults in Turkey, examining the prevalence of heart diseases as well as the risk factors for coronary heart disease. This nationwide survey has been a source of valuable information, especially since it was not limited to the investigation of one or other of the major risk factors but was rather a synchronous cross sectional assessment of most measurable risk factors combined with an examination of the prevalence of heart diseases.

This study describes the plasma total cholesterol and triglyceride profiles in adults in Turkey, comparing them with those of certain other nations and analysing the interrelations between cholesterol and triglyceride, relative weight, physical activity, and family income. Analysis of the young adult sample population provides additional data on the rise in serum cholesterol levels in a population.

\section{Methods}

The survey on the prevalence of cardiac disease and risk factors in adults in Turkey includes 3689 men and women 20 years of age and over residing in 59 different communities scattered over all the seven geographical regions of Turkey. The criteria for selecting the urban and rural communities, participating subjects, the surveying teams and the steering committee, methods of data collection, and the data obtained in the questionnaire have been presented in a separate report. ${ }^{2}$ Briefly, a random sample of the Turkish adult population was surveyed with the purpose of determining the prevalence of heart diseases and the risk factors for coronary artery disease. The sample was representatively stratified for sex, age, and geographical region as well as for the rural-urban distribution.

In this study a community was defined as rural when it had a population less than 8000 and urban when its population exceeded this figure. Communities were selected in the sample so that the same proportion of the rural population $(43 \%)$ and of cities with a population over $500000(27 \%)$ was present as in the whole of Turkey $(43.7 \%$ and $23.4 \%$ respectively). Towns with intermediate populations were also represented proportionately in the sample.

In the selection of participants from the various communities, the number of subjects in each age group was predetermined. When each surveying team reached the sample community, they first obtained information from the local authority about the socioeconomic distribution of the living quarters, and then rang randomly preselected doors in the evening and gave appointments for an 
examination the next morning. Roughly $60-90$ persons were invited for examination to obtain a mean of 62 persons per community to be surveyed. The ratio of responders exceeded $85 \%$. Males and females were partly selected from the same, and partly from different households. The sample did not include participants using lipid lowering drugs. In over $65 \%$ of participants ( 1151 men and 1257 women) blood was sampled in the postabsorptive state $12-15 \mathrm{~h}$ after the last meal for total cholesterol, triglycerides, and glucose. In the remaining persons cholesterol alone was determined $1-5 \mathrm{~h}$ after the ingestion of a breakfast.

Three teams were formed, each consisting of two physicians in their fourth year of specialisation in internal medicine and a laboratory technician receiving postgraduate training in medical biology. A schedule was designed to examine 24-30 persons daily for 5-6 days a week to allow the completion of the survey within 8-11 weeks. The survey started on July 13th and ended late in September, 1990. The task of each physician was to examine the cardiovascular system and record the ECG. The technician obtained blood samples by finger prick using disposable lancets and determined the plasma concentrations of cholesterol, triglycerides, and glucose using the Reflotron apparatus. Logistics were provided by the Ministry of Health of the Turkish Republic, each team having a large ambulance with a driver at its disposal.

The Reflotron operators were given a course over two full days in Istanbul by Boehringer representatives to train them to operate the instrument and to become familiar with the use of pipettes and reagent sticks. By the end of this time it was felt they demonstrated competence in carrying out these operations. Subsequently all team members were given a training course over a period of two days by the supervising staff to aquaint them with the technique of random sampling, the approach to adopt in the communities, and other pertinent items.

Internal quality control was made with control sticks obtained from the manufacturer. These were utilised at the beginning and commonly also at the end of each day of surveying. Any sampled value above $7.76 \mathrm{mmol} /$ litre $(300 \mathrm{mg} / \mathrm{dl}$ ) or below $2.59 \mathrm{mmol} /$ litre $(100 \mathrm{mg} / \mathrm{dl})$ for cholesterol was remeasured at the same sitting, and both were recorded. External quality control was made with reference to the biochemistry laboratory of the Admiral Bristol Hospital, Istanbul, certified for accuracy by the Center for Disease Control,

Table I Mean plasma total cholesterol and triglyceride concentrations in Turkish adults in various age groups (in mmol/litre)

\begin{tabular}{|c|c|c|c|c|c|c|c|c|}
\hline \multirow{3}{*}{$\begin{array}{l}\text { Age groups } \\
\text { (years) }\end{array}$} & \multicolumn{4}{|l|}{ Men } & \multicolumn{4}{|c|}{ Women } \\
\hline & \multicolumn{2}{|c|}{ Cholesterol } & \multicolumn{2}{|c|}{ Triglyceride } & \multicolumn{2}{|c|}{ Cholesterol } & \multicolumn{2}{|c|}{ Triglyceride } \\
\hline & $n$ & Mean $(S D)$ & $n$ & Mean (SD) & $n$ & Mean $(S D)$ & $n$ & Mean (SD) \\
\hline $\begin{array}{l}20-29 \\
30-39 \\
40-49 \\
50-59 \\
60-69 \\
70 \text { and }\end{array}$ & $\begin{array}{l}601 \\
424 \\
296 \\
258 \\
206\end{array}$ & $\begin{array}{l}3.82(0.91) \\
4.51(0.98) \\
4.86(1.07) \\
4.89(1.14) \\
4.75(1.06)\end{array}$ & $\begin{array}{l}316 \\
263 \\
198 \\
172 \\
146\end{array}$ & $\begin{array}{l}1.20(0.76) \\
1.69(1.12) \\
1.84(1.14) \\
1.62(0.99) \\
1.48(0.89)\end{array}$ & $\begin{array}{l}584 \\
411 \\
291 \\
252 \\
199\end{array}$ & $\begin{array}{l}3.97(0.91) \\
4.43(0.92) \\
4.87(1.00) \\
5.27(1.04) \\
5.28(1.17)\end{array}$ & $\begin{array}{l}373 \\
271 \\
228 \\
192 \\
140\end{array}$ & $\begin{array}{l}1.01(0.55) \\
1.20(0.71) \\
1.41(0.77) \\
1.55(0.94) \\
1.77(1.05)\end{array}$ \\
\hline over & 82 & $4.58(1.01)$ & 56 & $1.30(0.56)$ & 83 & $5.02(0.88)$ & 53 & $1.60(0.97)$ \\
\hline $\begin{array}{l}\text { Total } \\
\text { urban } \\
\text { Total rural }\end{array}$ & $\begin{array}{r}1065 \\
802 \\
\end{array}$ & $\begin{array}{l}4.47(1.09) \\
4.37(1.05)\end{array}$ & $\begin{array}{l}646 \\
505\end{array}$ & $\begin{array}{l}1.56(1.04) \\
1.47(0.90)\end{array}$ & $\begin{array}{r}1034 \\
786\end{array}$ & $\begin{array}{l}4.63(1.09) \\
4.53(0.99)\end{array}$ & $\begin{array}{l}706 \\
551\end{array}$ & $\begin{array}{l}1.34(0.78) \\
1.29(0.83)\end{array}$ \\
\hline
\end{tabular}

Houston Branch, USA. Venous blood samples were drawn by each team once or twice a week into tubes containing $1 \mathrm{mg} / \mathrm{dl}$ of EDTA as anticoagulant and were placed into dry tubes after centrifugation, to be forwarded the same day via aeroplane to the reference laboratory, which determined the cholesterol concentration by the enzymatic method using Boehringer (Mannheim) kits. A total of 212 samples was sent. These samples were obtained on 17 different days from participants residing in 13 cities which were served by an airline. A random selection of one in four blood samples was selected on that day for validation.

The Reflotron apparatus indicated triglyceride levels below $0.79 \mathrm{mmol} /$ litre $(70 \mathrm{mg} / \mathrm{dl})$ as such, without specifying accurately. Subjects with such values comprised $23.8 \%$ of those in whom blood was sampled for triglycerides. By plotting a histogram of the log normal distribution it was estimated that values shown as less than $0.79 \mathrm{mmol} /$ litre corresponded to a mean of $0.62 \mathrm{mmol} /$ litre. This presumed figure was used in calculating mean values in the respective age groups in men and women.

Physical examination consisted of weighing and measuring the surveyed person without shoes and heavy outer garments; palpation of the character, site, and size of cardiac impulses; auscultating the heart sounds and identifying murmurs; and measuring the blood pressure twice in the sitting position in the right arm. Body mass index was calculated by the computer as weight divided by height squared $\left(\mathrm{kg} / \mathrm{m}^{2}\right)$ to characterise the relative weight of the participants. All survey data were checked by the supervising staff before being included in the database, so as to ensure data quality and completeness.

The effect of physical activity upon the blood concentration of cholesterol was studied in this survey in four categories: grade 1 (minimal): white collar worker, sewing-knitting, walking $<1 \mathrm{~km}$ daily; grade 2 (slight): repair worker, housework, walking 1-2 km daily; grade 3 (moderate): mason, carpenter, truck driver, cleaning floors and windows, walking $4 \mathrm{~km}$ daily; grade 4 (heavy): heavy labour, farming, regular sports activity.

The correlation coefficient between two studied variables was determined and when found sufficiently high the regression equation between them was computed according to the method of Pearson-Bravais.

\section{Results}

VALIDATION STUDY

In 212 plasma samples in which the total cholesterol concentration was measured by both the Reflotron and the reference laboratory, the correlation coefficient between individual values was 0.90 . The mean concentration determined in the reference laboratory was $4.36 \mathrm{mmol} /$ litre $(168.6 \mathrm{mg} / \mathrm{dl}$ ) resulting in a bias of $+0.063 \mathrm{mmol} /$ litre $(+2.42 \mathrm{mg} / \mathrm{dl})$. This bias, representing a deviation of $+1.44 \%$, is acceptable. ${ }^{3}$

MEAN PLASMA CHOLESTEROL

Mean plasma total cholesterol values of 3687 participants, stratified into sex, age group, and urban or rural residence, are presented in table I 
and graphically depicted in fig 1 . Low average cholesterol concentrations prevailed in Turkish men and women in the age group 20-29 years ( 3.82 and $3.97 \mathrm{mmol} /$ litre, respectively, or 148 and $153 \mathrm{mg} / \mathrm{dl}$ ). These values rise rapidly in the age group 30-39 years to $4.5 \mathrm{mmol} /$ litre (174 $\mathrm{mg} / \mathrm{dl})$ in men and $4.43 \mathrm{mmol} / \mathrm{litre}(171 \mathrm{mg} / \mathrm{dl})$ in women, and further to $4.86 \mathrm{mmol} /$ litre $(188$ $\mathrm{mg} / \mathrm{dl}$ ) in both sexes in the age bracket $40-49$ years. Within two age groups 20 years apart this represents a $27 \%$ rise in Turkish males and $23 \%$ in females. As in surveys of other communities males in this survey reached a plateau in the $40-49$

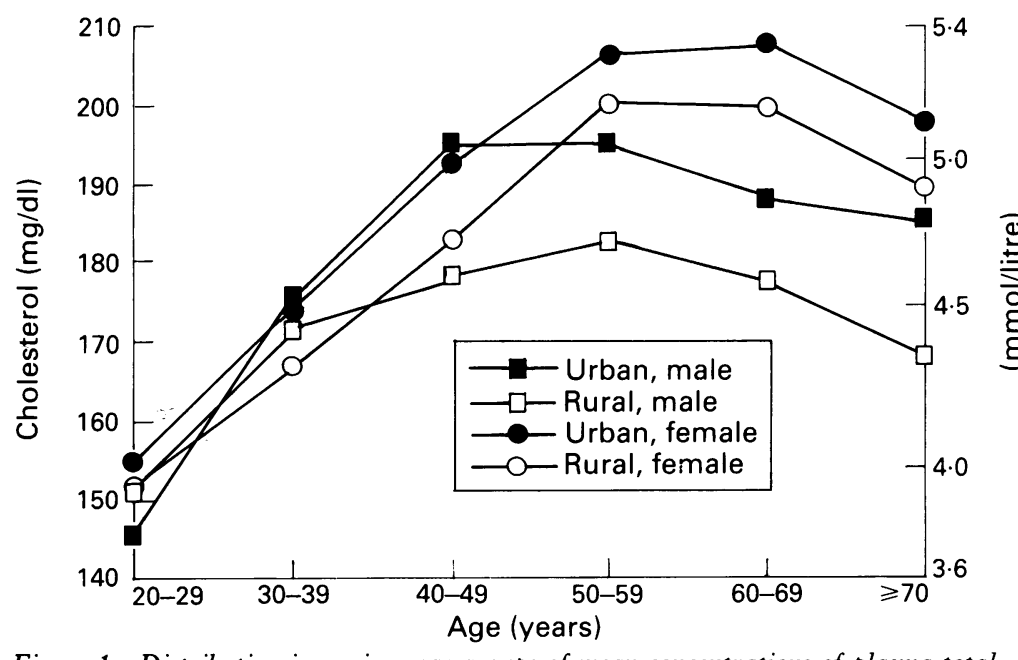

Figure 1 Distribution in various age groups of mean concentrations of plasma total cholesterol in Turkish subjects of urban and rural residence

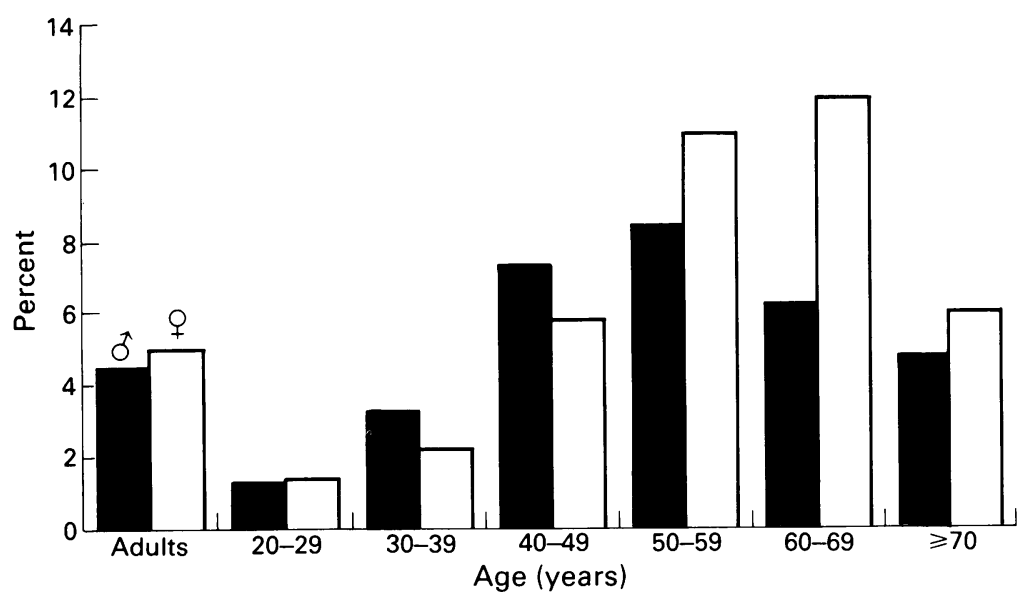

Figure 2 The prevalence of hypercholesterolaemia ( $\geqslant 6.5 \mathrm{mmol} /$ litre, $>250 \mathrm{mg} / \mathrm{dl}$ ) in various age groups of Turkish adults by sex $(n=3687)$.

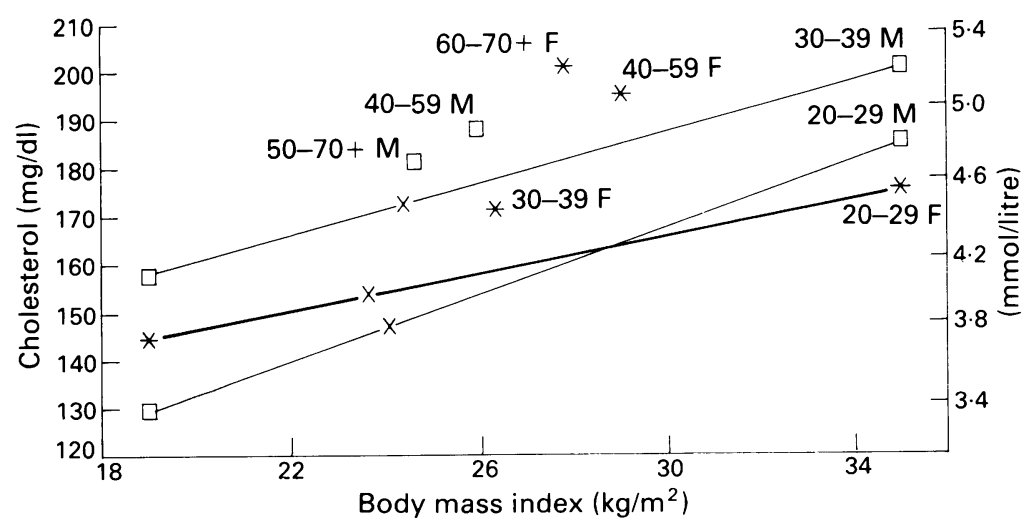

Figure 3 Relation between body mass index (BMI) in $\mathrm{kg} / \mathrm{m}^{2}$ and plasma cholesterol by certain age groups in males $(M)$ and females $(F)$. Mean values only are plotted for the age groups where their regression equations failed to be significant year age period, with a mean value of $4.9 \mathrm{mmol} /$ litre $(189 \mathrm{mg} / \mathrm{dl})$ in the $50-59$ year age group and a slight decline to $4.76 \mathrm{mmol} /$ litre $(184 \mathrm{mg} / \mathrm{dl})$ in the 60-69 year age group, and further to $4.58 \mathrm{mmol} /$ litre $(177 \mathrm{mg} / \mathrm{dl})$ at age 70 and over. In women, mean total cholesterol reached a plateau of $5.27 \mathrm{mmol} /$ litre a decade later, in the 50-59 year age group, and this persisted in the subsequent decade before declining to $5 \mathrm{mmol} /$ litre (194 $\mathrm{mg} / \mathrm{dl}$ ) at age 70 and over. From age 40 years onwards, total cholesterol values were on average $0.35 \mathrm{mmol} /$ litre $(13.5 \mathrm{mg} / \mathrm{dl})$ higher in urban males than in their rural counterparts $(p<0.001)$, a difference of $7 \%$. Urban women of the same age also had higher total cholesterol than rural women, but the difference was less, namely $0.22 \mathrm{mmol} /$ litre $(8.4 \mathrm{mg} / \mathrm{dl})$, equivalent to $4.4 \%(\mathrm{p}<0.01)$.

Female participants over 40 years of age had higher mean total cholesterol concentrations than males; the difference was more pronounced among rural residents at $0.38 \mathrm{mmol} /$ litre $(14.4 \mathrm{mg} / \mathrm{dl})(\mathrm{p}<0.001)$ than among the urban population $(0.27 \mathrm{mmol} /$ litre, $9.6 \mathrm{mg} / \mathrm{dl}, \mathrm{p}<0.01)$.

PREVALENCE OF HYPERCHOLESTEROLAEMIA

In the general adult sample population of 3687 subjects, the following total cholesterol percentile values were observed, in $\mathrm{mmol} / \mathrm{litre}(\mathrm{mg} / \mathrm{dl}): 10$ th percentile: $3 \cdot 16$ (122); 25 th percentile: $3 \cdot 73$ (144); median: 4.45 (172); 90th percentile: 5.92 (229); 95th percentile: $6 \cdot 44(249)$. The following cut off values were noted: $4.7 \%$ over $6.45 \mathrm{mmol} /$ litre $(250 \mathrm{mg} / \mathrm{dl}), 0.7 \%$ over $7.76 \mathrm{mmol} /$ litre $(300$ $\mathrm{mg} / \mathrm{dl}$ ). The prevalence of hypercholesterolaemia (defined as $6.5 \mathrm{mmol} /$ litre and over, or over $250 \mathrm{mg} / \mathrm{dl}$ ) in various age groups in each sex is presented in fig 2 .

The interrelations between plasma cholesterol concentration and certain variables such as body mass index, physical activity, triglycerides, and income level were investigated. With the purpose of eliminating age as a joint determinant of serum cholesterol, the relation between the latter and body mass index was sought in various age groups. This relationship was significant in men solely in the age groups $20-29$ years $(\mathrm{y}=[63+3.48 \mathrm{x}] \pm 33.3 ; \mathrm{r}=0.32)$ and $30-39$ years $(y=[107+2 \cdot 69 x] \pm 36 \cdot 6 ; r=0 \cdot 26)$, and in women in the age group $20-29$ years $(y=[107 \cdot 6+1 \cdot 95 x]$ $\pm 34.5 ; \mathrm{r}=0.24)$. Hence, as indicated by the coefficients, in Turkish men aged 20-39 years each unit of body mass index raised the mean cholesterol level by slightly over $0.08 \mathrm{mmol} /$ litre $(3 \mathrm{mg} / \mathrm{dl})$ and in women by $0.05 \mathrm{mmol} /$ litre (2 mg/dl) (fig 3).

Age standardisation was performed using fixed weights of five age groups in each category of physical activity in urban and rural population with separate but minimally different weighting for men and women. The mean total cholesterol values in each grade of physical activity among adults of age 20-69 years are represented in fig 4 . As activity grade increased from 1 to 4 , cholesterol concentrations declined in men from 4.76 to $4.19 \mathrm{mmol} /$ litre, diminishing at each activity grade by a mean of $0.57 \mathrm{mmol} /$ litre. Similarly, plasma cholesterol decreased in women from $4.74 \mathrm{mmol} /$ litre to $4.3 \mathrm{mmol} /$ litre, by an average of $0.15 \mathrm{mmol} /$ litre for each increase in physical activity grade. Figure 4 clearly indicates that 
lower cholesterol values occur with increasing grades of physical activity in both the rural and the urban population, and in women as well as in men. Due to the relatively small size of the sample of rural women in activity grade 1 and of urban women in grade 4 , the related separate urban-rural data may have limited reliability. However, data in the other three activity grades in women and all those in men possess a sufficiently broad base and are consistent in showing a definite trend of

Table II Plasma cholesterol values by physical activity grades computed in Turkish adults of selected age from regression equations. Values are means ( $S D$ )

\begin{tabular}{rlll}
\hline & \multicolumn{3}{l}{ Plasma cholesterol (mmol/litre) } \\
\cline { 2 - 4 } & Grade 2 & Grade 3 & Grade 4 \\
\hline Man, aged 25 & $4.64(1.07)$ & $4.28(0.96)$ & $4.03(0.88)$ \\
aged 50 & $5.11(1.07)$ & $4.96(0.96)$ & $4.94(0.88)$ \\
Woman, aged 25 & $4.45(1.04)$ & $4.36(0.86)$ & $4.04(0.75)$ \\
aged 50 & $5.43(1.04)$ & $5.25(0.86)$ & $5.23(0.75)$ \\
\hline
\end{tabular}

Table III Distribution centrations in adults 40 to 59 years of age by geoTurkey (in mmol/litre) of plasma cholesterol congraphical regions in

\begin{tabular}{|c|c|c|c|c|}
\hline \multirow[b]{2}{*}{ Regions } & \multicolumn{2}{|c|}{ Men } & \multicolumn{2}{|c|}{ Women } \\
\hline & $n$ & Mean (SD) & $n$ & Mean (SD) \\
\hline $\begin{array}{l}\text { Marmara } \\
\text { Black Sea } \\
\text { Aegean } \\
\text { Central Anatolia } \\
\text { East Anatolia } \\
\text { Southeast Anatolia } \\
\text { Mediterranean }\end{array}$ & $\begin{array}{r}138 \\
64 \\
82 \\
126 \\
51 \\
47 \\
46\end{array}$ & $\begin{array}{l}\cdot 14(1 \cdot 1) \\
5.09(1 \cdot 1) \\
4.93(1 \cdot 2) \\
4.93(1 \cdot 1) \\
4.63(0.8) \\
4.54(0.8) \\
4 \cdot 17(0.9)\end{array}$ & $\begin{array}{r}133 \\
64 \\
82 \\
122 \\
51 \\
46 \\
45\end{array}$ & $\begin{array}{l}5.28(1.0) \\
5.05(1.0) \\
5.17(1.0) \\
5.02(0.9) \\
4.91(0.8) \\
4.87(0.9) \\
4.73(1.0)\end{array}$ \\
\hline Turkey & 554 & $4 \cdot 88(1 \cdot 1)$ & 543 & $5 \cdot 06(1 \cdot 0)$ \\
\hline
\end{tabular}

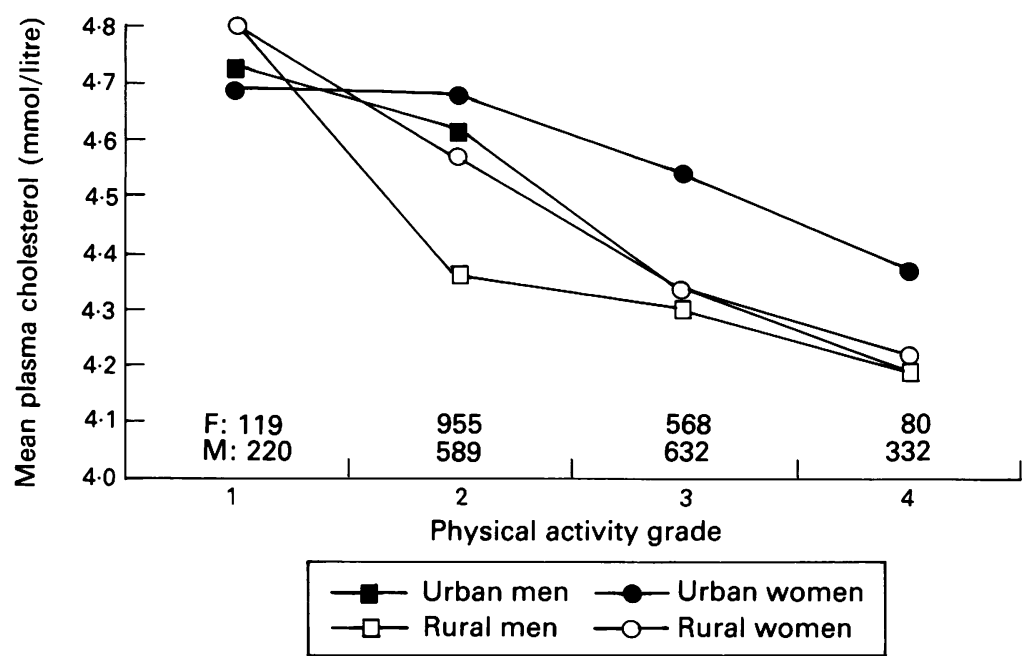

Figure 4 Mean plasma cholesterol after adjustment for age, by grades of physical activity in urban and rural men and women aged 20 to 69 years

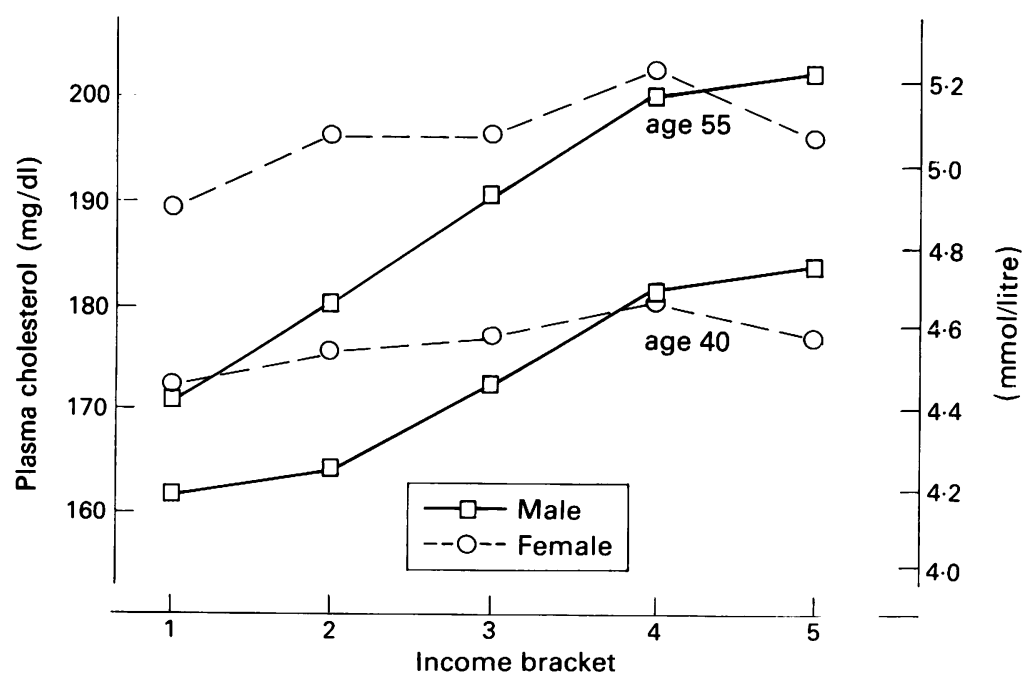

Figure 5 Relation between mean plasma cholesterol values and family income levels in Turkish men and women decreasing cholesterol levels with rising physical activity. Over three activity grades, a reduction in the mean cholesterol value of $12 \%$ was observed in urban and rural men. An effect of similar magnitude prevailed in rural women, but it was less in urban women, at only $7 \%$.

In examining the effect of physical activity on plasma cholesterol, another approach was to plot the regression line between age and cholesterol in the various grades of physical activity. Though at grade 1 there was no significant correlation, the correlation coefficients for higher grades were of sufficient magnitude $(0.24$ to 0.40 in men, 0.43 to 0.52 in women) to define the relationship between age and cholesterol (table II). Worthy of note is that between grades 2 and 4 of activity, mean plasma cholesterol values varied in men aged 25 to 50 years by 0.17 to $0.61 \mathrm{mmol} / \mathrm{litre}$, and in women of similar age by 0.20 to $0.41 \mathrm{mmol} /$ litre. It appears that the role of physical activity in moderating serum cholesterol greatly diminishes after age 50 years.

The income level also appeared to influence the mean plasma cholesterol concentrations, in men more clearly than in women. When the regression equation was determined between average serum cholesterol value and a particular family income bracket for certain ages, it was observed that for a man aged 40 years (or 55 years) the mean cholesterol concentration in the highest income bracket exceeded by $0.55 \mathrm{mmol} /$ litre (or $0.79 \mathrm{mmol} /$ litre) that in the lowest bracket. The magnitude of the effect of income level on plasma cholesterol in women was about two fifths of that in men at age 40 years, and about one third at age 55 years (fig 5 ). When the influence of urban-rural living was examined, it was found that the positive relation between family income and mean cholesterol did not exist in rural women, but persisted in urban women as well as in urban and rural men. Between the lowest and highest income brackets in a 40 (or 55) year old man, the mean cholesterol gradient amounted to 0.48 (or 0.60 ) $\mathrm{mmol} /$ litre in both the urban and the rural sectors. (The subset of rural men with the highest income bracket was not taken into account, since no valid regression equation was obtained due to small sample size).

Plasma cholesterol data for men and women aged 40-59 years (with identical weighting of the two age groups) in various geographical regions of Turkey are presented in table III. When assessed for men and women combined, the Marmara region ranks top, the Mediterranean and southeast Anatolia regions rank lowest, while the remaining four regions rank in the middle with a mean cholesterol value varying closely around $5 \mathrm{mmol} /$ litre.

TRIGL YCERIDE CONCENTRATIONS

Plasma triglyceride concentrations showed a log normal distribution. Mean triglyceride values in the Turkish adult sample are presented by gender and age groups in table I, and certain percentile values are shown graphically in fig 6 . The latter data indicate that median values in men attain a plateau between the ages 35-55 years of around $1.55 \mathrm{mmol} /$ litre $(137 \mathrm{mg} / \mathrm{dl}$ ) before declining, whereas in women a progressive rise is observed, from $0.8 \mathrm{mmol} /$ litre in the age group $20-29$ years to a peak of $1.58 \mathrm{mmol} /$ litre in age group $60-69$ 
years. Mean values standardised for age 30-69 years were $1.68 \mathrm{mmol} /$ litre in men and $1.42 \mathrm{mmol} /$ litre in women. Hypertriglyceridaemia, defined as $2.26 \mathrm{mmol} /$ litre $(200 \mathrm{mg} / \mathrm{dl})$ and over, prevailed in $9.8 \%$ of all adult women and $14.8 \%$ of men. In the decades spanning the ages $40-69$ years, $14 \cdot 7 \%$ of women and $19.3 \%$ of men were found to be hypertriglyceridaemic.

A positive relationship existed between body mass index and mean plasma triglyceride concentration in adults aged 20 to 49 years, but not in those aged 50 years and over (fig 7). In men, a rise of $0.08-0.09 \mathrm{mmol} / \mathrm{litre}(7-8 \mathrm{mg} / \mathrm{dl})$ was noted for each unit increment in body mass index, while the corresponding rise in women was barely half that $(0.04 \mathrm{mmol} /$ litre, or $3.5 \mathrm{mg} / \mathrm{dl})$.

Data available on plasma concentrations of both total cholesterol and triglyceride in 2408 individuals were computed to provide regression equations between the cholesterol values and those of triglyceride and age. The following equations were obtained (units $=\mathrm{mg} / \mathrm{dl}$ ):

In men : cholesterol $=114 \cdot 6+(0 \cdot 201$ triglyceride $)+(0 \cdot 77$ age $)$ $\mathrm{r}=0.50, \mathrm{p}<0.001$

In women: $\quad$ cholesterol $=112 \cdot 3+(0 \cdot 191$ triglyceride $)+(1.08$ age $)$, $\mathrm{r}=0.55, \mathrm{p}<0.001$

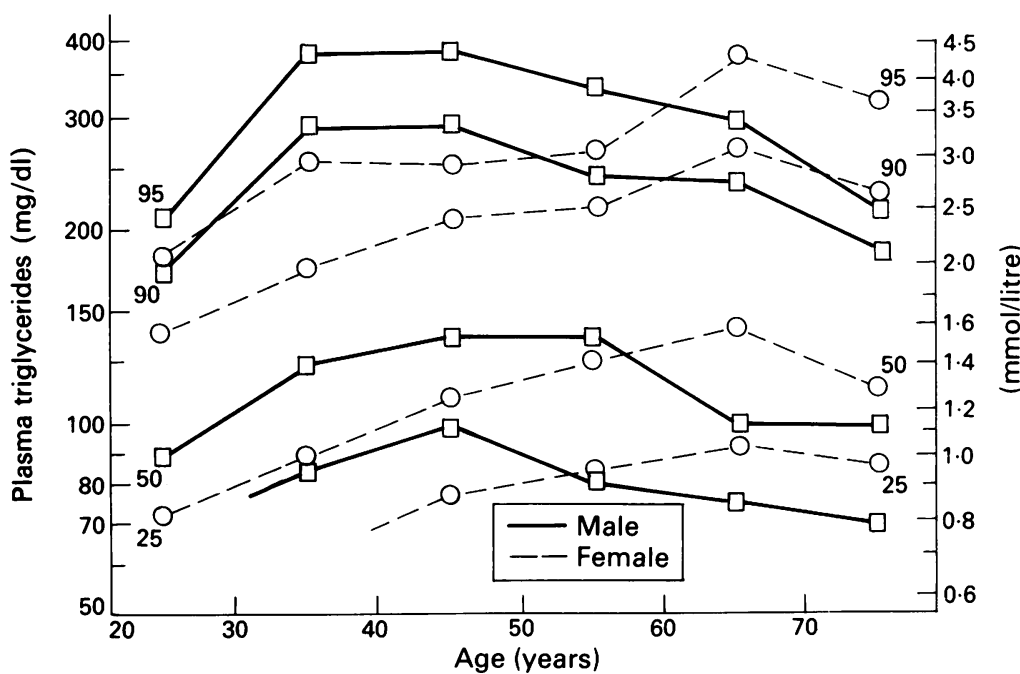

Figure 6 Percentile values for plasma triglycerides by age group in Turkish men and women (semilogarithmic scale)

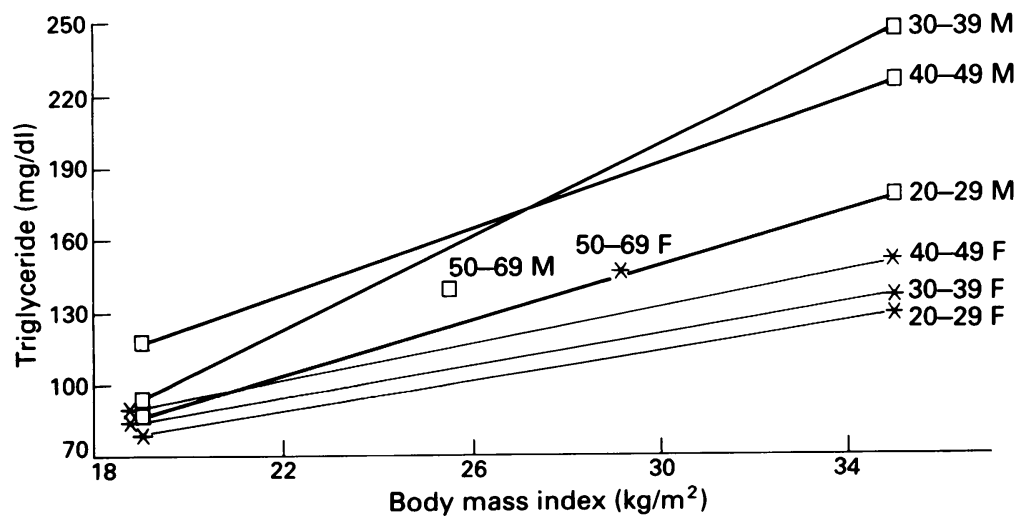

Figure 7 Relation between plasma triglyceride and body mass index by certain age groups in males $(M)$ and females $(F)$. For the age group 50-69 years only mean values are plotted ( $r=$ not significant
The equation implies a change of $1 \mathrm{mg} / \mathrm{dl}$ in cholesterol for each change of about $5 \mathrm{mg} / \mathrm{dl}$ in plasma triglyceride in our sample population.

\section{Discussion}

Two indices of an acceptable accuracy of cholesterol measurement exist in this study. (1) Though a conventional biochemical method was used in the reference laboratory in contrast to a "dry chemistry" method by the Reflotron apparatus in the survey, the bias between the mean of the two sets of measurements was small $(+1 \cdot 4 \%)$, and the correlation between individual measurements was high $(r=0.90)$. (2) The "interior consistency" of the data is apparent: the rise of cholesterol values during early adulthood, the delayed attainment of the plateau in women compared to men, the fall past the age of 70 years, the relationship with triglycerides and body mass index, etc.

It is important to bear in mind that the median age of the population surveyed was only 37 years, so that the overall mean of cholesterol values has limited significance. When age adjustment is performed according to World Health Organization criteria, ${ }^{4}$ Turkish men had a mean value of $4.8 \mathrm{mmol} /$ litre $(185 \mathrm{mg} / \mathrm{dl})$, and women $5.0 \mathrm{mmol} /$ litre $(192 \mathrm{mg} / \mathrm{dl})$. These cholesterol concentrations are far lower than are found in northern European countries and lie in the lower range of the Mediterranean populations. For an overall comparison one may recall that, excluding Beijing, China, the mean age adjusted blood cholesterol values in the 30 communities included in the MONICA project ranged between 5.3 and $6.4 \mathrm{mmol} /$ litre in men and about $0.1 \mathrm{mmol} /$ litre higher in women. ${ }^{4}$ The areas of Bremen, Belfast, and Charleroi assumed a median position among these communities, with mean values of 6.0 to $6.1 \mathrm{mmol} /$ litre. Thus Turkish men have age adjusted average total cholesterol values of $1.1 \mathrm{mmol} /$ litre lower, and women $0.9-1.0 \mathrm{mmol} /$ litre lower, than in the mentioned cities of the developed world.

When comparison is made with the data of the Lipid Research Clinics ${ }^{56}$ a striking parallel was seen during adult life between the cholesterol curve of white American men and that of Turkish men between the ages of 20 and 59 years, the latter being on average $0.6 \mathrm{mmol} /$ litre lower than the former (and somewhat more from the age of 60 on). The difference between Turkish and American women in the age range 20 to 59 years was about $0.4 \mathrm{mmol} /$ litre $(15 \mathrm{mg} / \mathrm{dl})$ in favour of the former.

Although the present study is merely of a cross sectional nature, with limited longitudinal implications, it is worth pointing out the steep rise in mean cholesterol levels in Turkish subjects observed between the age groups 20-29 years and 40-49 years. Young male and female Turks appear to enter adulthood with very low cholesterol levels, only $0.4 \mathrm{mmol} /$ litre higher than those of the Chinese, ${ }^{7}$ yet their mean cholesterol concentration rises by $1 \mathrm{mmol} /$ litre $(39 \mathrm{mg} / \mathrm{dl})$, equivalent to $25 \%$, in this period of two decades. This is an appreciably steeper rate of rise than in available studies for other populations. As calculated by us, data from US adults ${ }^{56}$ show an $18 \%$ rise, almost identical to the findings from 
Italy $^{8}(17.4 \%)$. Data from Japan ${ }^{9}$ show a rise of $12 \%$ and from $\mathrm{China}^{7}$ a rise of $11 \%$. In the study of 12092 British men and women reported by Mann et al, ${ }^{10}$ mean plasma total cholesterol values in both sexes were $5.15 \mathrm{mmol} /$ litre at age 25-29 years and increased to $6 \mathrm{mmol} /$ litre at age $45-49$ years. The "rise" within the age groups two decades apart was $16.5 \%$. The increase in total cholesterol concentration in this earlier period of adulthood is known to stem primarily from an augmentation in low density lipoprotein (LDL) cholesterol, ${ }^{611}$ and this is in turn believed to reflect a progressive decrease in LDL catabolism with age which, particularly in women, could reflect hormonal changes. ${ }^{11}$ However, the observation that a significant rise in cholesterol concentrations in early adulthood is lacking in some African sample populations ${ }^{12}$ implies that underlying environmental factors also play a role in this phenomenon after the age of about 25 years.

This survey revealed significantly higher mean cholesterol values in the urban population than in the rural population, by on average $4 \%$ in women and $8 \%$ in men. Between the urban and rural sample population in Augsburg, Germany, the difference was far less, namely $0.1 \mathrm{mmol} /$ litre both in men and women. ${ }^{4}$ It is worth noting that no significant difference existed in our survey between urban and rural participants with regard to the prevalence of hypertension in either sex, or smoking in men.

The prevalence of hypercholesterolaemia (defined as a level greater than $6.5 \mathrm{mmol} / \mathrm{litre}$ or $250 \mathrm{mg} / \mathrm{dl}$ ) in Turkish men of 40-59 years of age was $8 \%$ and was thus comparable to that of Yugoslavia and Japan, but moderately lower than that of Italy $(13 \%)$ and Greece $(14 \%)$, found in the Seven Country Study. ${ }^{13}$

A recent study estimated the average consumption of "visible" fats (butter, fats, and oils) in Turkey as $37 \mathrm{~g} /$ caput/d. Reliable data on consumption of "invisible" fats (cheese, other dairy products, and meat) are not available, and data on the regional distribution of consumed "visible" fats have limited reliability. Nonetheless, it is generally considered that the people of Marmara and Black Sea regions consume most fat, and the intake of those inhabiting the Mediterranean and southeast Anatolia regions is the least. Our data on the mean serum cholesterol concentrations by geographical region indicate a parallel trend.

Combined assessment both of work and leisure activity by questionnaire appeared to affect mean serum cholesterol values substantially, though it failed to affect the percentage of cigarette smokers and, in women, the body mass index; it marginally influenced the latter in men and the blood pressure in both sexes. Our age adjusted findings indicated that, independent of urban-rural differences and over a wide age range, as physical activity increased from grade 1 to 4 , a decline in mean plasma cholesterol by $12 \%$ in men and by $10 \%$ in women occurred. A similar effect of leisure activity was observed by Hickey and coworkers $^{14}$ in a study of coronary risk factors related to physical activity in 15171 Irish men: the magnitude of reduction in serum cholesterol in men younger than 41 years $(0.06 \mathrm{mmol} /$ litre $)$ was comparable to that in the present survey. However, in the MRFIT trial, ${ }^{15}$ in which 12138 men were classified by questionnaire into three groups according to their leisure activity, no significant difference of mean serum total cholesterol was observed in the three activity levels.

Increasing net family income from the lowest to the highest of five brackets was associated with a successive and substantial rise by $13.2 \%$ in average plasma cholesterol values in middle aged men and by a smaller rise in women. This appeared to be independent of urban life in men, but was related to urban life in women. Various factors, including higher dietary saturated fatty acids, diminished physical activity, and psychosocial stress, are likely determinants for this observation. In 14677 men aged $40-49$ years included in the Oslo study, it was noted that serum cholesterol and triglyceride concentrations decreased with increasing socioeconomic status. ${ }^{16}$ The decrease in serum cholesterol was $4.7 \%$ and in serum triglyceride, $19.5 \%$. This study, combined with our present survey, support the view that improved economic status from a low base is accompanied by a rise in blood cholesterol values up to a level when further improvement in socioeconomic status, resulting in more widespread awareness of health issues and adoption of low fat diets, leads to a decline in the lipid values.

The triglyceride profile in Turkish adults seems not to be as favourable as that of cholesterol. The mean serum triglyceride concentration of Turkish men up to the age of 55 years exceed by almost $0.1 \mathrm{mmol} /$ litre that of their American ${ }^{56}$ and Italian ${ }^{8}$ counterparts, though the values are slightly lower than those in British ${ }^{10}$ and German ${ }^{17}$ men. Triglyceride levels in Turkish women exceed by about $0.1 \mathrm{mmol} /$ litre those found in American women and in women in western European nations. The relatively high triglyceride values are probably related to the higher relative body weight of Turkish women; thus $47 \%$ of Turkish women aged $40-59$ years had a body mass index in excess of $29 \mathrm{~kg} / \mathrm{m}^{2}$, while $13-31 \%$ of European women of the same age had a body mass index exceeding $30 \mathrm{~kg} / \mathrm{m}^{2}$ in the WHO ERICA project. ${ }^{18}$

As regards the relation between the levels of plasma triglyceride and cholesterol, it is reassuring to note in our sample population that for each rise of $5 \mathrm{mg} / \mathrm{dl}$ triglyceride an increase in cholesterol of $1 \mathrm{mg} / \mathrm{dl}$ occurred in both men and women, which confirmed the well known Friedewald formula ${ }^{19}$ concerning the very low density lipoprotein (VLDL) required for the transport of triglyceride in plasma and VLDLcholesterol.

In conclusion, the study of a representative sample of Turkish adults, comprising women as well as men over a full age range of adult life, allowed us to characterise the cholesterol profile of the inhabitants of a developing Mediterranean country and to analyse the relationship with total cholesterol of variables such as sex, age, urban residence, physical activity, body mass index, family income, and plasma triglyceride level.

We appreciate the dedicated work of Drs Y Karaaslan, $M$ Işler, U Özıșlk, the coworkers in the survey teams, that of Ş Gedikli, E Ince, G Gökyar, L Baradarani, the Reflotron operators and that of $\mathrm{V}$ Taskın and OO OOZ in the data processing. The support of Professor $\mathrm{Dr} R$ Özcan, President of the Turkish Society of Cardiology is 
deeply appreciated. We thank Professor Dr K Pyörälä (Kuopio) and Dr G Pfaff (Heidelberg) for their fruitful suggestions and encouragement and Unilever-Is (Istanbul) for partial financial support.

1 Wynder EL, Blackburn H, Lewis B, Wissler R. Plasma lipids. Optimal levels for health. (American Health Foundation). New York: Academic Press, 1980.

2 Onat A, Surdum-Avci G, Şenocak M, Örnek E, Özcan R Türkiye'de eriskinlerde kalp hastalığ 1 ve risk faktörleri sikliği taramasi: 1 . Yöntemin tarifi. Türk Kardiyol Dern Ars 1991; 19: 9-15.

3 Naughton MJ, Luepker RV, Strickland D. The accuracy of portable cholesterol analyzers in public screening programs. FAMA 1990; 263: 1213-7.

4 The WHO MONICA Project. Geographical variation in the major risk factors of coronary heart disease in men and women aged 35-64 years. World Health Stat 1988; 41 115-40.

5 The Lipid Research Clinics Program Epidemiology Committee. Plasma lipid distributions in selected North American populations: the Lipid Research Clinics Program prevalence study. Circulation 1979; 60: 427-39.

6 Heiss G, Tamir I, Davis CE et al. Lipoprotein-cholesterol distributions in selected North American populations: the Lipid Research Clinics Program prevalence study. Circulation 1980; 61: 302-15.

7 Chen H, Zhuang H, Han Q. Serum high density lipoprotein cholesterol and factors influencing its level in healthy cholesterol and factors influencing its
Chinese. Arteriosclerosis 1983; 48: 71-9.

8 The Research Group ATS-RF2 of the Italian National Research Council. Distribution of some risk factors for atherosclerosis in nine Italian population samples. $\mathrm{Am}$ Epidemiol 1981; 113: 338-46.
9 Sekimoto H, Goto Y, Goto Y, et al. Changes in serum total cholesterol and triglyceride levels in normal subjects in Japan in the past twenty years. $\mathcal{F p}_{n} \operatorname{Circ} \mathcal{F} 1983 ; 47: 1351-8$ 10 Mann JI, Lewis B, Shepherd J, et al. Blood lipid concentrations and other cardiovascular risk factors distribution, prevalence and detection in Britain. $B M \mathcal{Y}$ 1988; 296: 1702-6.

11 Thompson GR. A handbook of hyperlipidaemia. London: Current Science Ltd, 1990: 211.

12 Knuiman JT, West CE, Burema J. Serum total and high density lipoprotein cholesterol concentrations and body mass index in adult men from 13 countries. $A m \mathcal{F}$ Epidemiol 1982; 116: 631-42.

13 Keys A. Coronary heart disease in seven countries. Circulation 1970; 41 (suppl 1): $1-199$.

14 Hickey N, Mulcahy R, Bourke GJ, Graham I, Wilson-Davis Hickey N, Mulcahy R, Bourke GJ, Graham I, Wilson-Davis
K. Study of coronary risk factors related to physical activity in 15171 men. $B M 71975$; iii: $507-9$.

15 Leon AS, Connett J, Jacobs DR, Rauramaa R. Leisure-time physical activity levels and risk of coronary heart disease and death (the Multiple Risk Factor Intervention Trial) fAMA 1987; 258: 2388-94.

16 Holme I, Hjermann I, Helgeland A, Lund-Larsen PG Leren $\mathrm{P}$. Coronary risk factors and socioeconomic status: the Oslo Study. Lancet 1976; ii: 1396-8.

17 Assmann G, Schulte H. Results and conclusions of the Prospective Cardiovascular Münster (PROCAM) Study. In: Assmann G, ed. Lipid metabolism disorders and coronary heart disease. München: MMV Medizin Verlag, 1989: 131 .
Lamm G (WHO ERICA Research Group). The risk-map of Lamm G (WHO ERICA Research Gro
Europe. Ann Med 1989; 21: 189-92.

19 Friedewald WT, Levy RI, Fredrickson DS. Estimation of the concentration of low-density lipoprotein cholesterol in plasma, without use of the preparative ultracentrifuge. Clin Chem 1972; 18: 499-502. 